Archive for

Organic Chemistry

Arkivoc 2018, part vii, 0-0

\title{
Synthesis and study of electrochemical behavior of new 4-ferrocenylbutylamine derivatives
}

\author{
Elmira Payami, Hassan Abbasi, Elaheh S. Yazdchi, Kazem D. Safa, and Reza Teimuri-Mofrad* \\ Department of Organic and Bio-Organic Chemistry, Faculty of Chemistry, University of Tabriz, Tabriz, Iran \\ Email: teymouri@tabrizu.ac.ir
}

Received 08-29-2018

Accepted 11-17-2018

Published on line $12-02-2018$

\section{Abstract}

Ferrocene derivatives play important roles in the fields of biological, material and synthetic chemistries. Some 4-ferrocenylbutylamine derivatives were synthesized by the nucleophilic-substitution reactions of 4bromobutylferrocene with various aliphatic and aromatic secondary amines, and their electrochemical properties have been investigated. The electrochemical behavior of the synthesized compounds was studied by cyclic voltammetry. The relationship between the peak currents and the square root of the scan rate showed that the redox process is diffusion limited.

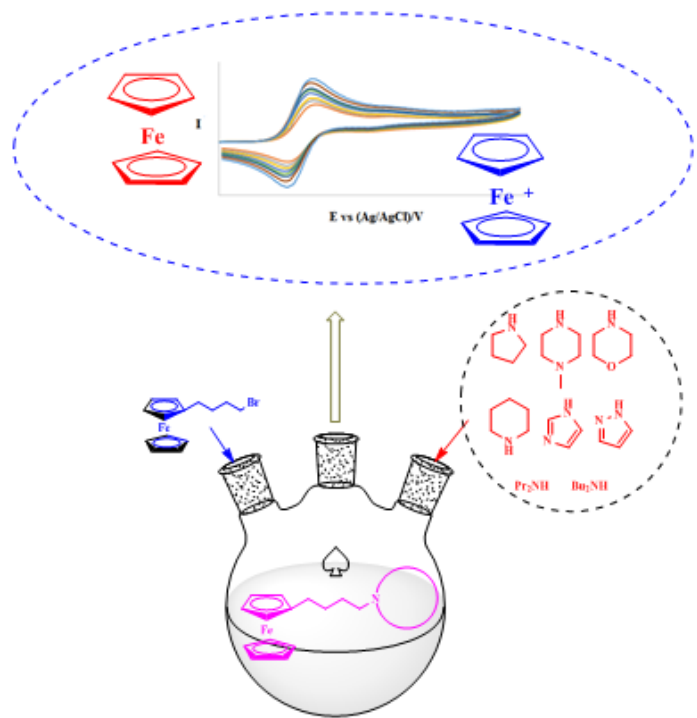

Keywords: 4-Ferrocenylalkylamine, $\mathrm{S}_{\mathrm{N}} 2$ reaction, ferrocene, cyclic voltammetry 


\section{Introduction}

Ferrocene or di (n5-cyclopentadienyl) iron (II) was accidentally discovered by Peter L. Pauson and Tom Kealy in 1951 when they attempted the reductive coupling of the Grignard reagent cyclopentadienyl magnesium bromide in the presence of ferric chloride. The unique sandwich structure of ferrocene was first predicted by infrared and nuclear magnetic resonance spectroscopies, and later confirmed by X-ray crystallography in 1954. ${ }^{1}$

Ferrocene derivatives play important roles in the fields of synthetic, material and biological chemistries. Hence, chemists began to synthesize various ferrocene derivatives and investigated their applications in various scientific fields. ${ }^{2}$ The ferrocenyl group plays an important role in electron-transfer reactions, which are involved in many living systems, and in synthetic chemistry as multi-redox nano systems, especially, in ferrocenyl polymers, ${ }^{3}$ dendrimers, ${ }^{4}$ nanoparticles, ${ }^{5}$ vectors, ${ }^{6}$ biosensors, ${ }^{7}$ biological-redox processes, $^{8}$ molecular conductors and semiconductors, ${ }^{9}$ mixed-valence stabilizers, ${ }^{10}$ catalytic reactions, ${ }^{11}$ redox recognition, ${ }^{12}$ as redox reagents, ${ }^{13}$ redox catalysts, ${ }^{14}$ electron-transfer catalysts, ${ }^{15}$ sensors, ${ }^{16}$ and green catalysts. ${ }^{17}$ Ferrocenyl compounds possess many cytotoxic properties including antitumour effects, ${ }^{18}$ antimalarial $^{19}$ and anti-cancer effect in human lung cancer cells. ${ }^{20}$ Many ferrocenyl derivatives display interesting cytotoxic, antifungal and DNA-cleaving activities. ${ }^{21}$

The development of new methods for the formation of carbon-nitrogen bonds is an interesting challenge in organic synthesis. ${ }^{22} \mathrm{~A}$ variety of powerful approaches have been devised, including venerable processes such as reductive amination ${ }^{23}$ and Ullmann coupling, ${ }^{24}$ as well as the more recently developed BuchwaldHartwig reaction. ${ }^{25}$ Despite the utility of such processes, the discovery of novel methods for the formation of carbon-nitrogen bonds remains an important objective. ${ }^{26,27}$ Perhaps the most classic reported approach in the literature for carbon-nitrogen bond formation is the reaction of an amine with an alkyl halide, ${ }^{28,29}$ a transformation that continues to play an important role in amine-derivatives synthesis. ${ }^{30}$ Because this process generally follows a $S_{N} 2$ pathway, elevated reaction temperatures are typically employed for hindered primary and secondary electrophiles that are inactivated. ${ }^{22}$ Due to the interesting electrochemical properties of the ferrocene moiety, research and investigations of chemical and electrochemical properties of ferrocenyl organic molecules are important. Cyclic voltammetry (CV) is a very useful electroanalytical technique for the characterization of the electroactive species. This method provides valuable information regarding the stabilities of the oxidation states and the rate of electron transfer between the electrode and the analyte. Applications of cyclic voltammetry have been extended to almost every aspect of chemistry, e.g., the investigation of biosynthetic reaction pathways, the examination of the ligand effect on the metal complex potential, and enzymatic catalysis. ${ }^{31,32}$

We report, herein, the synthesis and electrochemical properties of some 4-ferrocenylbutylamine derivatives and obtain information about substituent effects on the electrochemical properties of the ferrocene moiety using cyclic voltammetry.

\section{Results and Discussion}

Due to interesting electronic properties of ferrocene and its derivatives, ${ }^{33-37}$ we decided to synthesize a series of novel 4-ferrocenylbutylamine derivatives. Initially, 4-chlorobutylferrocene (2) was synthesized from ferrocene (1) as shown in Scheme $1 .^{33}$ Subsequent reduction with $\mathrm{NaBH}_{4}$ solution in diglyme provided the corresponding 4-chlorobutylferrocene (3). 


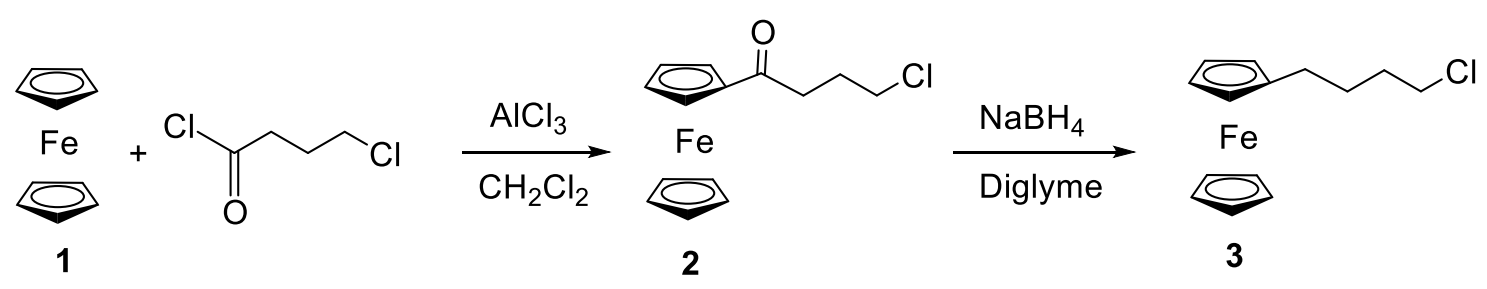

Scheme 1. Synthesis of 4-chlorobutylferrocene (3).

Compound $\mathbf{3}$ was subsequently treated with pyrrolidine in acetonitrile as solvent in reflux conditions. After $24 \mathrm{~h}$, the reaction was not complete; the desired compound was obtained in only $20 \%$ yield (Table 1, Entry 6). To increase the efficiency and improve the reaction conditions, the 4-bromobutylferrocene (4) was synthesized (Scheme 2).

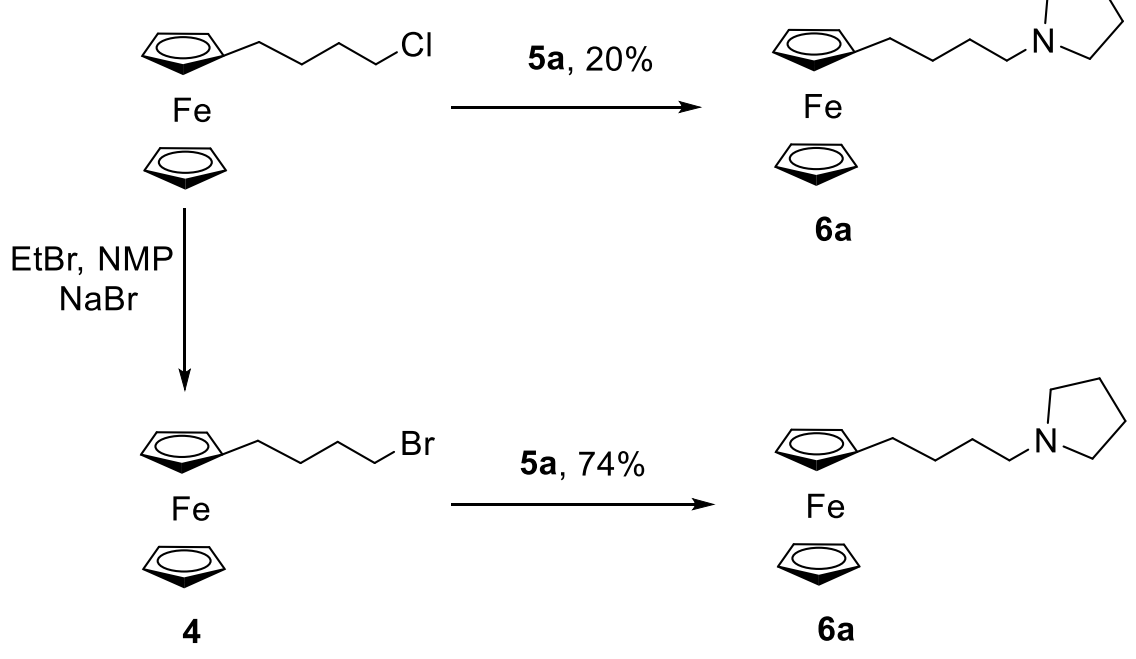

Scheme 2. Synthesis of 1-(4-butylferrocene)pyrrolidine (6a).

To optimize the reaction conditions for synthesis of 4-ferrocenylbutylamine derivatives, a variety of solvents and bases were tested, as shown in Table 1. Among the various solvents and bases screened at $80{ }^{\circ} \mathrm{C}$, the best results were obtained when acetonitrile was used as a solvent and $\mathrm{K}_{2} \mathrm{CO}_{3}$ was employed as the base (Table 1, Entries 2 and 9).

After optimization of the reaction conditions, to explore the scope and generality of the optimal method, we investigated the synthesis of the corresponding 4-ferrocenylbutylamine derivatives (6a-h) via the $\mathrm{N}$ alkylation of compound $\mathbf{4}$ with a variety of aliphatic and aromatic amines (5a-h) (Scheme 3). Saturated secondary amines such as dipropylamine, dibutylamine, pyrrolidine, morpholine, piperidine and $\mathrm{N}$-methyl piperazine show good reactivity in $\mathrm{S}_{\mathrm{N}} 2$ reactions with compound 4; morpholine showed the best reactivity (Table 2, Entry 3). Aromatic amines undergo the same reaction with compound 4, and the results showed that aromatic amines such as imidazole and pyrazole afforded the 4-ferrocenylbutylamines in good yield. 
Table 1. Optimization of nucleophilic substitution $\left(S_{N} 2\right)$ reaction conditions for synthesis of 6 a

\begin{tabular}{|c|c|c|c|c|c|}
\hline Entry & $X$ & Solvent & Base & Temp. $\left({ }^{\circ} \mathrm{C}\right)$ & Yield (\%) \\
\hline 1 & $\mathrm{Br}$ & $\mathrm{CH}_{3} \mathrm{CN}$ & $\mathrm{Na}_{2} \mathrm{CO}_{3}$ & 80 & 43 \\
\hline 2 & $\mathrm{Br}$ & $\mathrm{CH}_{3} \mathrm{CN}$ & $\mathrm{K}_{2} \mathrm{CO}_{3}$ & 80 & 74 \\
\hline 3 & $\mathrm{Br}$ & $\mathrm{CH}_{3} \mathrm{CN}$ & $\mathrm{Et}_{3} \mathrm{~N}$ & 80 & 37 \\
\hline 4 & $\mathrm{Br}$ & $\mathrm{CH}_{3} \mathrm{CN}$ & $\mathrm{NaHCO}_{3}$ & 80 & 29 \\
\hline 5 & $\mathrm{Br}$ & $\mathrm{H}_{2} \mathrm{O}$ & $\mathrm{K}_{2} \mathrm{CO}_{3}$ & 80 & 40 \\
\hline 6 & $\mathrm{Br}$ & $\mathrm{EtOH}$ & $\mathrm{K}_{2} \mathrm{CO}_{3}$ & reflux & 35 \\
\hline 7 & $\mathrm{Br}$ & Toluene & $\mathrm{K}_{2} \mathrm{CO}_{3}$ & 80 & 38 \\
\hline 8 & $\mathrm{Cl}$ & $\mathrm{H}_{2} \mathrm{O}$ & $\mathrm{K}_{2} \mathrm{CO}_{3}$ & 80 & 5 \\
\hline 9 & $\mathrm{Cl}$ & $\mathrm{CH}_{3} \mathrm{CN}$ & $\mathrm{K}_{2} \mathrm{CO}_{3}$ & 80 & 20 \\
\hline 10 & $\mathrm{Cl}$ & $\mathrm{EtOH}$ & $\mathrm{K}_{2} \mathrm{CO}_{3}$ & reflux & 15 \\
\hline 11 & $\mathrm{Cl}$ & Toluene & $\mathrm{K}_{2} \mathrm{CO}_{3}$ & 80 & 10 \\
\hline
\end{tabular}
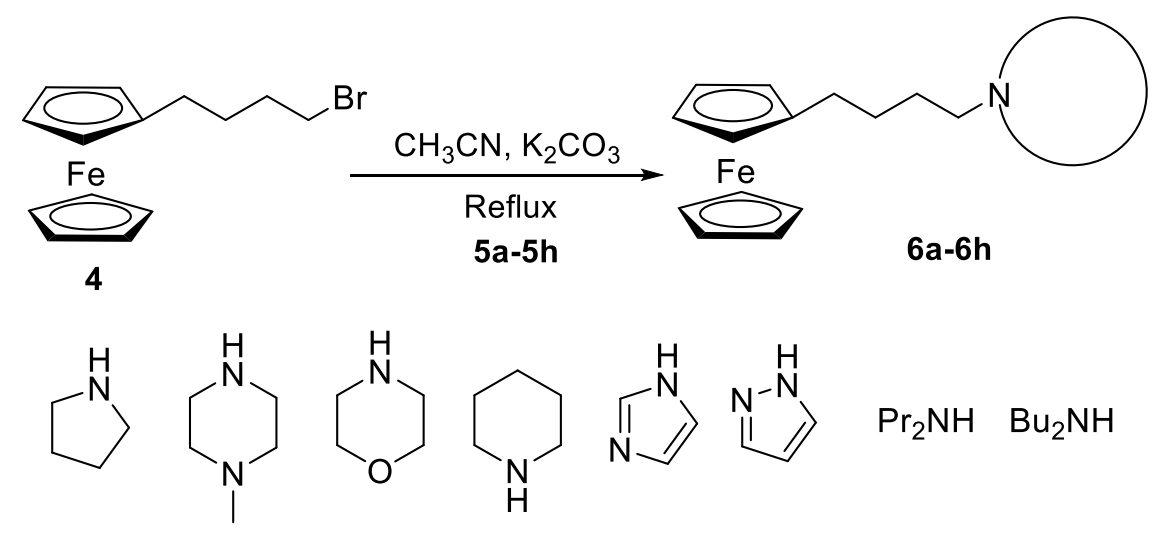<smiles>C1CCNCC1</smiles><smiles>c1c[nH]c(-c2ccn[nH]2)c1</smiles>

$\mathrm{Pr}_{2} \mathrm{NH} \quad \mathrm{Bu}_{2} \mathrm{NH}$

5a-5h: $\quad 5 a$ $5 b$

$5 c$

$5 d \quad 5 e \quad 5 f \quad 5 g$

$5 \mathrm{~h}$

Scheme 3. Synthesis of 4-ferrocenylbutylamine derivatives (6a-6h).

Subsequently, we synthesized the corresponding ferrocenyl-based ammonium salts from the morpholine derivative $(\mathbf{6 c})$ by treating $\mathbf{6 c}$ with Mel to produce the ferrocenyl-based morpholinium iodide salt (6i) in very good yield (Table 2, Entry 9).

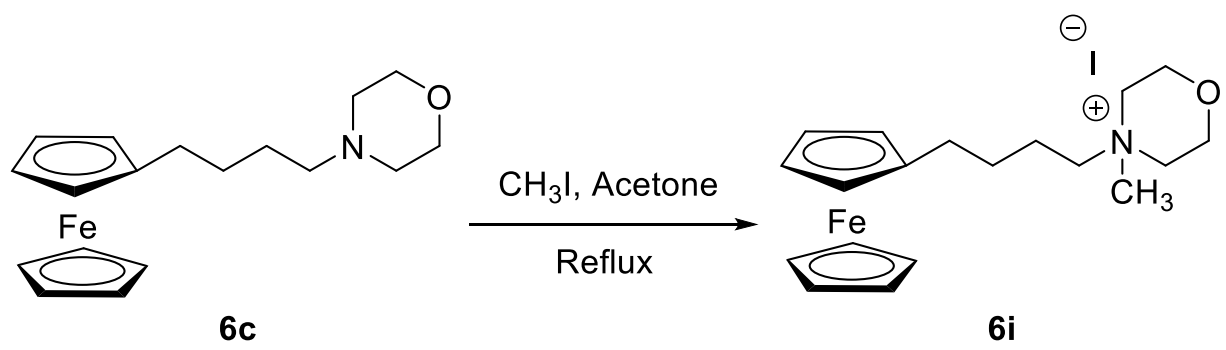

Scheme 4. Synthesis of 4-(4-ferrocenylbutyl)-4-methyl morpholinium iodide (6i) from compound 6c. 
Table 2. Yields of compound (6a-i) under optimal conditions ${ }^{a}$

\begin{tabular}{ccc}
\hline Entry & Product & ${\text { Yield }(\%)^{\text {b }}}^{\circ}$ \\
\hline 1 & $6 \mathbf{a}$ & 74 \\
2 & $\mathbf{6 b}$ & 82 \\
3 & $\mathbf{6 c}$ & 87 \\
4 & $\mathbf{6 d}$ & 71 \\
5 & $\mathbf{6 e}$ & 73 \\
6 & $\mathbf{6 f}$ & 57 \\
7 & $\mathbf{6 g}$ & 69 \\
8 & $\mathbf{6 h}$ & 78 \\
9 & $\mathbf{6 i}$ & 91 \\
\hline
\end{tabular}

${ }^{a} \mathrm{~K}_{2} \mathrm{CO}_{3}, \mathrm{CH}_{3} \mathrm{CN}$, reflux

${ }^{b}$ Isolated yield

\section{Cyclic voltammetry}

To compare the influence of the substituents on the redox ability of Fe (II), electrochemical studies on the synthesized ferrocene derivatives (6a-i) were carried out. Cyclic voltammetry (CV) experiments performed in dry $\mathrm{CH}_{3} \mathrm{CN} / 0.01 \mathrm{M} \mathrm{LiClO}_{4}$ solution exhibited quasi-reversible voltammetric behavior for the ferrocenyl group in these compounds, with $\Delta \mathrm{Ep}=\mathrm{Epa}-\mathrm{Epc}<0.07 \mathrm{~V}$ at scan rates up to $0.15 \mathrm{~V} \mathrm{~s}^{-1}$ (Table 3). Cathodic and anodic peak current ratios measured for the derivatives were in the range $1.07<\mathrm{ipc} / \mathrm{ipa}<1.13$, and Ep values were independent of the scan rate.

Table 3. Selected potentials $(\mathrm{V})$ and current $(\mathrm{mA})$ data for $1.0 \mathrm{mM}$ solutions of the 4-ferrocenylbutylamines (6a-i) in $\mathrm{CH}_{3} \mathrm{CN} / 0.1 \mathrm{M} \mathrm{LiClO}_{4}$

\begin{tabular}{cccc}
\hline Entry & Compound & $\Delta$ Ep & Ipc / Ipa \\
\hline 1 & $\mathbf{6 a}$ & 0.065 & 1.13 \\
2 & $\mathbf{6 b}$ & 0.069 & 1.08 \\
3 & $\mathbf{6 c}$ & 0.067 & 1.11 \\
4 & $\mathbf{6 d}$ & 0.071 & 1.07 \\
5 & $\mathbf{6 e}$ & 0.062 & 1.12 \\
6 & $\mathbf{6 f}$ & 0.069 & 1.08 \\
7 & $\mathbf{6 g}$ & 0.068 & 1.07 \\
8 & $\mathbf{6 h}$ & 0.071 & 1.12 \\
9 & $\mathbf{6 i}$ & 0.062 & 1.10 \\
\hline
\end{tabular}

All of the newly synthesized compounds (6a-6i) exhibited only one pair of well-defined redox peaks in $\mathrm{CH}_{3} \mathrm{CN}$ indicating the existence of only one kind of electroactive center in these compounds which correspond to its ferrocenyl group. A series of voltammograms of the ferrocene compounds in $\mathrm{CH}_{3} \mathrm{CN} / 0.100 \mathrm{M} \mathrm{LiClO}$, at various scan rates, such as 50,60,70, 80, 90, 100, 120 and $150 \mathrm{mVs}^{-1}$, were also recorded, as shown in Figure 1. It was found that both cathodic- and anodic-peak currents linearly increase with the increasing of scan rate. The position of the cathodic peak slightly shifted towards the negative potential, and the anodic peak shifted a little towards the positive direction with increase of scan rate. The plots of the anodic and cathodic currents 
versus the square root of scan rates $\left(v^{1 / 2}\right)$ show a linear relationship. This behavior suggests that the redox process is diffusion limited (Figure 2).

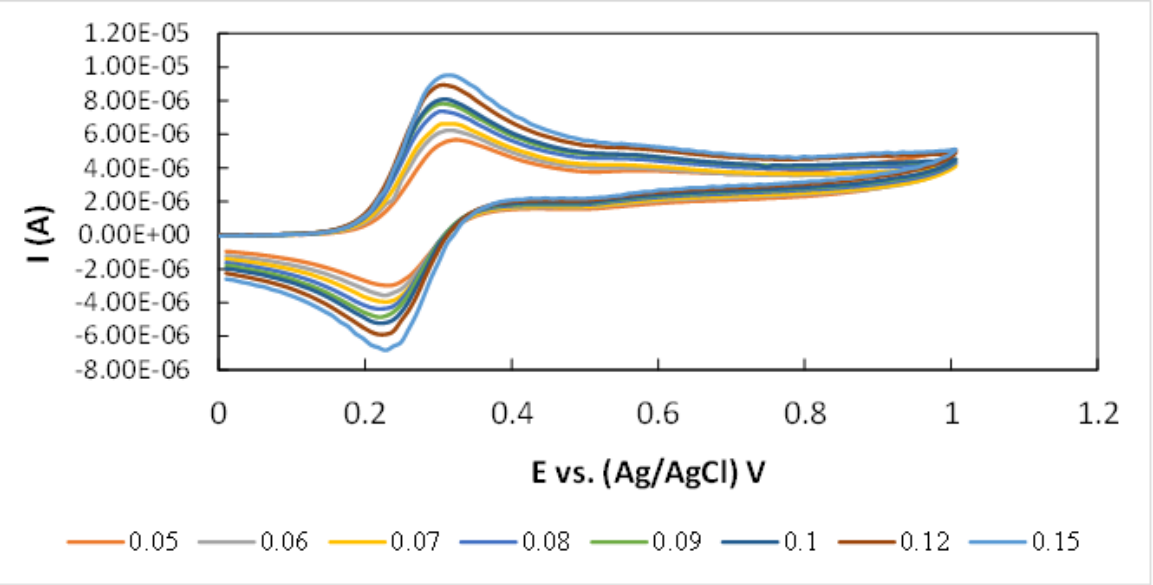

Figure 1. CV curves of the 1-(4-ferrocenylbutyl)pyrrolidine (6a) in different scan rates.

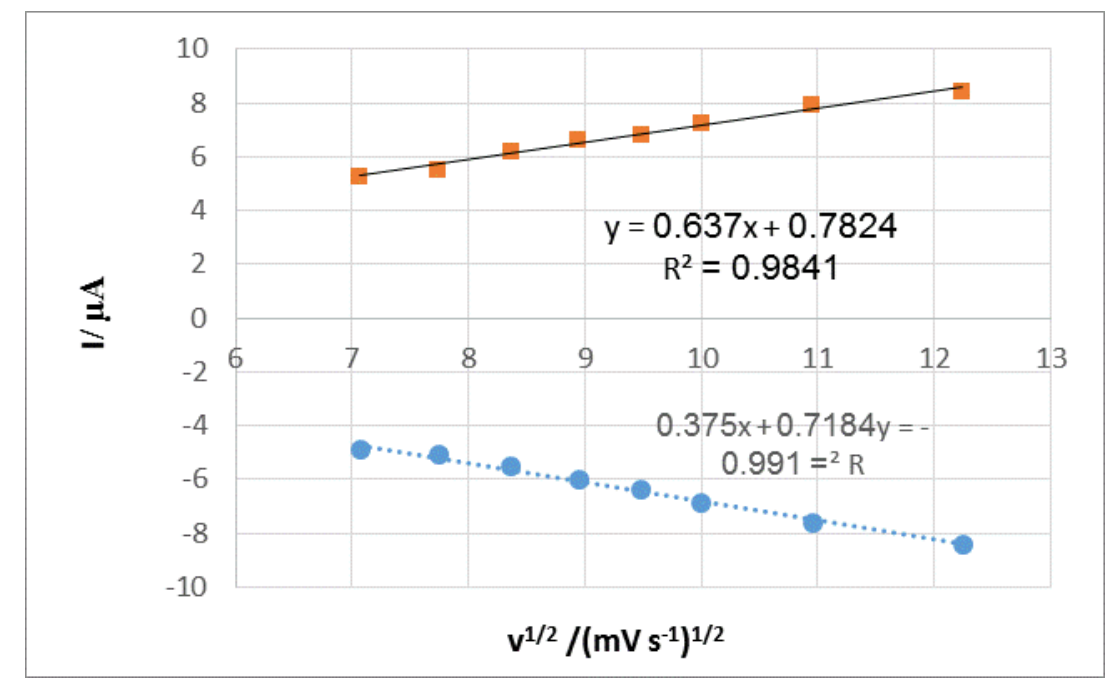

Figure 2. Linear relationship between the A) cathodic peak current, B) anodic peak current and the square root of the scan rates.

As indicated in Table 3, electrochemical parameters, such as the position of redox potentials and degree of reversibility of the electrochemical behavior, are negligibly affected by the presence and type of the amine functional groups attached to the central ferrocene rings. Therefore, it can be said that nature of the appending groups does not significantly affect the electrochemical properties of the ferrocene rings.

\section{Conclusions}

In summary, we report the synthesis of some 4-ferrocenylbutylamine derivatives in good yields through the substitution reactions of 4-bromobutylferrocene with various secondary aliphatic and aromatic amines. The 
electrochemical behavior of the synthesized compounds with the increase of scan rate was investigated. Based on the results, the synthesized 4-ferrocenylbutylamine derivatives showed quasi-reversible singleelectron electroactivity. The relationship between the peak currents and the square root of the scan rate showed that the electrode processes were diffusion controlled.

\section{Experimental Section}

General. Chemicals were either prepared in our laboratory or purchased from Merck, Sigma-Aldrich and Yantai Suny Chem. International Co., Ltd. Commercial solid reagents were used without further purification. Liquid reactants were distilled prior to use. Solvents were dried and distilled prior to use according to standard laboratory practices; water was doubly distilled. THF and diglyme were dried by refluxing under argon over sodium wire and distilled directly before use.

The ${ }^{1} \mathrm{H}$ NMR and ${ }^{13} \mathrm{C}$ NMR spectra were recorded at room temperature using a Bruker FT- $400 \mathrm{MHz}$ and 100 $\mathrm{MHz}$ spectrometer, respectively. $\mathrm{CDCl}_{3}$ was used as solvent and internal standard, and chemical shifts are presented with delta-values expressed in ppm referenced to $\mathrm{CDCl}_{3}$ peaks at $7.25\left({ }^{1} \mathrm{H} \mathrm{NMR}\right)$ and $78 \mathrm{ppm}\left({ }^{13} \mathrm{C}\right.$ NMR), respectively. The FT-IR spectra were recorded on a Bruker-Tensor 270 spectrophotometer as $\mathrm{KBr}$ disks or smears between salt plates. Elemental analyses were carried out with an Elementor Vario EL. III instrument. Iron analysis was performed using an Analytikjene (novaa 400) Atomic Absorption Spectrophotometer. Cyclic voltammetry measurements were performed on $1 \mathrm{mM}$ solutions of ferrocene derivatives in dry $\mathrm{CH}_{3} \mathrm{CN} / 0.1 \mathrm{M}$ $\mathrm{LiClO}_{4}$ using potentiostat/galvanostat Autolab (PGASTAT 30) equipped with a standard three-electrode cell. A 2-mm-diameter GC was used as the working electrode. A silver/silver chloride $(\mathrm{Ag} / \mathrm{AgCl})$ electrode and a platinum electrode were used as the reference and counter electrodes, respectively. All potentials in this study are reported with respect to the $\mathrm{Ag} / \mathrm{AgCl}$ electrode.

Synthesis of 4-chlorobutylferrocene (3). The procedure for synthesis of 4-chlorobutylferrocene was carried out according to the reported method. ${ }^{33}$

Synthesis of 4-bromobutylferrocene (4). The procedure for synthesis of 4-bromobutylferrocene was carried out according to the reported method. ${ }^{34}$

General procedure for the synthesis of 4-ferrocenylbutylamine derivatives (6a-6h). 4-bromobutylferrocene (4) $(0.4 \mathrm{~g}, 1.2 \mathrm{mmol})$, the appropriate amine derivatives $(4.7 \mathrm{mmol})$ and potassium carbonate $(0.63 \mathrm{~g}, 5.94$ $\mathrm{mmol})$ were dissolved in acetonitrile $(25 \mathrm{ml})$. The mixture was refluxed for 48 hours. After the completion of the reaction, acetonitrile was evaporated under vacuum, and the cooled residue mixture was diluted with 25 $\mathrm{ml}$ of $\mathrm{CH}_{2} \mathrm{Cl}_{2}$ and washed with water $(3 \times 10 \mathrm{ml})$. The organic phase was dried over $\mathrm{Na}_{2} \mathrm{SO}_{4}$, filtered and the solvent was removed under atmospheric pressure. The crude products were purified by preparative thin layer chromatography on silica gel with EtOAc/MeOH (9:1) as eluent. Specific details are described for each of the compounds.

1-(4-Ferrocenylbutyl)pyrrolidine (6a). From $0.4 \mathrm{~g}$ of 4-bromobutylferrocene, $0.25 \mathrm{~g}$ of light brown oil viscous oil (6a) was obtained in $67 \%$ yield. FT-IR $\left(\mathrm{KBr}, \mathrm{cm}^{-1}\right): 3085,2926,2855,1669,1457,1360,1094,1021,488 .{ }^{1} \mathrm{H}$ NMR $\left(400 \mathrm{MHz}, \mathrm{CDCl}_{3}\right): \delta_{\mathrm{H}} 1.52-1.56\left(4 \mathrm{H}, \mathrm{m},-\mathrm{CH}_{2}-\right), 1.84\left(4 \mathrm{H}, \mathrm{m},-\mathrm{CH}_{2}-\right), 2.32-2.36\left(2 \mathrm{H}, \mathrm{t}, \mathrm{J} 7 \mathrm{~Hz} \mathrm{CpCH}_{2}\right), 2.52-$ $2.54(2 \mathrm{H}, \mathrm{m}, \mathrm{NCH} 2), 2.64\left(4 \mathrm{H}, \mathrm{br}, \mathrm{NCH}_{2}\right), 4.02-4.04(4 \mathrm{H}, \mathrm{d}, J 6.2 \mathrm{~Hz}, \mathrm{Cp}), 4.08(5 \mathrm{H}, \mathrm{s}, \mathrm{Cp}) .{ }^{13} \mathrm{C} \mathrm{NMR}(100 \mathrm{MHz}$, $\left.\mathrm{CDCl}_{3}\right): \delta_{c} 22.3,27.2,28.0,28.4,\left(-\mathrm{CH}_{2}-\right), 55.2,53.0\left(\mathrm{NCH}_{2}\right), 66.0,67.0,67.4(\mathrm{Cp}), 88.8$ (Cipso $\left.\mathrm{Cp}\right)$. Anal. Calc. for: $\mathrm{C}_{18} \mathrm{H}_{25} \mathrm{FeN}$ (311.25): C, 69.46; H, 8.10; Fe, 17.94; N, 4.50. Found: C, 69.78; H, 7.99; Fe, 17.82; N, 4.41\%. 
1-Methyl-4-(ferrocenylbutyl)piperazine (6b). From $0.4 \mathrm{~g}$ of 4-bromobutylferrocene, $0.35 \mathrm{~g}$ of light brown oil viscous oil (6b) was obtained in $87 \%$ yield. FT-IR (KBr, $\left.v_{\max } \mathrm{cm}^{-1}\right): 3090,2933,2796,1683,1455,1363,1011$, 486; ${ }^{1} \mathrm{H}$ NMR (400 MHz, $\left.\mathrm{CDCl}_{3}\right): \delta_{\mathrm{H}} 1.48-1.50\left(4 \mathrm{H}, \mathrm{m},-\mathrm{CH}_{2}-\right), 2.27\left(2 \mathrm{H}, \mathrm{s},-\mathrm{CH}_{3}\right), 2.31-2.35(4 \mathrm{H}, \mathrm{q}, \mathrm{J} 7 \mathrm{~Hz}, \mathrm{CpCH}$ ), 2.44-2.49 (8H, br, NCH 2$)$ 4.01-4.02 (4H, d, J $1.35 \mathrm{~Hz}, \mathrm{Cp}), 4.06(5 \mathrm{H}, \mathrm{s}, \mathrm{Cp}) .{ }^{13} \mathrm{C} \mathrm{NMR}\left(100 \mathrm{MHz}, \mathrm{CDCl}_{3}\right): \delta_{\mathrm{c}} 25.6$, 27.9, 28.3, $57.3\left(-\mathrm{CH}_{2}-\right), 44.8\left(-\mathrm{CH}_{3}\right), 51.1,53.8\left(\mathrm{CH}_{2} \mathrm{~N}\right), 65.9,66.9,67.3(\mathrm{Cp}), 87.9$ (C $\left.\mathrm{c}_{\text {ipso }} \mathrm{Cp}\right)$. Anal. Calc. for: $\mathrm{C}_{19} \mathrm{H}_{28} \mathrm{FeN}_{2}$ (340.29): C, 67.06; H, 8.29; Fe, 16.41; N, 8.23. Found: C, 66.83; H, 8.34; Fe, 16.51; N, 8.32\%.

1-(4-Ferrocenylbutyl)morpholine (6c). From $0.4 \mathrm{~g}$ of 4-bromobutylferrocene, $0.34 \mathrm{~g}$ of light brown oil viscous oil (6c) was obtained in 87\% yield. FT-IR $\left(\mathrm{KBr}, v_{\max }, \mathrm{cm}^{-1}\right)$ : 2923, 2854, 1665, 1469, 1362, 1057, 490; ${ }^{1} \mathrm{H}$ NMR $\left(400 \mathrm{MHz}, \mathrm{CDCl}_{3}\right): \delta_{\mathrm{H}} 1.49-1.53\left(4 \mathrm{H}, \mathrm{m},-\mathrm{CH}_{2}-\right), 2.31-2.35\left(4 \mathrm{H}, \mathrm{t}, \mathrm{J} 6.4 \mathrm{~Hz}, \mathrm{CpCH}_{2}\right), 2.43(4 \mathrm{H}, \mathrm{br}, \mathrm{NCH}) 3.70-3.72$ $\left(4 \mathrm{H}, \mathrm{m}, \mathrm{OCH}_{2}\right), 4.02-4.04(4 \mathrm{H}, \mathrm{d}, \mathrm{J} 4.96 \mathrm{~Hz}, \mathrm{Cp}), 4.08(5 \mathrm{H}, \mathrm{s}, \mathrm{Cp}) ;{ }^{13} \mathrm{C} \mathrm{NMR}\left(100 \mathrm{MHz}, \mathrm{CDCl}_{3}\right): \delta_{\mathrm{C}} 25.3,27.8,28.4(-$ $\left.\mathrm{CH}_{2-}\right), 57.8,52.6\left(\mathrm{NCH}_{2}\right), 65.1\left(\mathrm{OCH}_{2}\right), 65.8,66.9,67.3(\mathrm{Cp}), 87.9$ (Cipso $\left.\mathrm{Cp}\right)$; Anal. Calc. for: $\mathrm{C}_{18} \mathrm{H}_{25} \mathrm{FeNO}$ (327.25): C, 66.07; H, 7.70; Fe, 17.06; N, 4.28. Found: C, 65.92; H, 7.75; Fe, 17.11; N, 4.30\%.

1-(4-Ferrocenylbutyl)piperidine (6d). From $0.4 \mathrm{~g}$ of 4-bromobutylferrocene, $0.27 \mathrm{~g}$ of light brown oil viscous oil (6d) was obtained in 71\% yield. FT-IR ( $\left.\mathrm{KBr}, \mathrm{cm}^{-1}\right): 2933,2859,1649,1402,1366,1077,486 ;{ }^{1} \mathrm{H}$ NMR (400 $\left.\mathrm{MHz}, \mathrm{CDCl}_{3}\right): \delta_{\mathrm{H}} 1.50-1.51\left(2 \mathrm{H}, \mathrm{m},-\mathrm{CH}_{2}-\right), 1.52-1.57\left(4 \mathrm{H}, \mathrm{m},-\mathrm{CH}_{2}-\right), 1.57-1.62\left(4 \mathrm{H}, \mathrm{m},-\mathrm{CH}_{2}-\right), 2.28-2.31(4 \mathrm{H}, \mathrm{m}$, $\left.\mathrm{CH}_{2} \mathrm{~N}, \mathrm{CpCH}_{2}\right), 2.38\left(4 \mathrm{H}, \mathrm{br}, \mathrm{CH}_{2} \mathrm{~N}\right), 4.00-4.03(4 \mathrm{H}, \mathrm{d}, \mathrm{J} 1.6 \mathrm{~Hz}, \mathrm{Cp}), 4.06(5 \mathrm{H}, \mathrm{s}, \mathrm{Cp}) ;{ }^{13} \mathrm{C} \mathrm{NMR}\left(100 \mathrm{MHz}, \mathrm{CDCl}_{3}\right)$ :

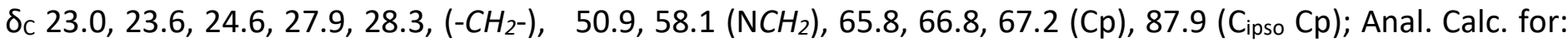
$\mathrm{C}_{19} \mathrm{H}_{27} \mathrm{FeN}$ (325.28): C, 70.16; H, 8.37; Fe, 17.17; N, 4.31. Found: C, 69.89; H, 8.47; Fe, 17.27; N, 4.37\%.

1-(4-Ferrocenylbutyl)imidazole (6e). From $0.4 \mathrm{~g}$ of 4-bromobutylferrocene, $0.27 \mathrm{~g}(73 \%)$ of light brown oil viscous oil (6e) was obtained. FT-IR $\left(\mathrm{KBr}, \mathrm{cm}^{-1}\right)$ : 2933, 2859, 1506, 1453, 1228, 1105, 1000, 650, 486; ${ }^{1} \mathrm{H}$ NMR $\left(400 \mathrm{MHz}, \mathrm{CDCl}_{3}\right): \delta_{\mathrm{H}} 1.42-1.50\left(2 \mathrm{H}, \mathrm{m},-\mathrm{CH}_{2^{-}}\right), 1.75-1.79\left(2 \mathrm{H}, \mathrm{m},-\mathrm{CH}_{2^{-}}\right), 2.32-2.36\left(2 \mathrm{H}, \mathrm{t}, J \mathrm{~J} .5 \mathrm{~Hz}, \mathrm{CpC} \underline{\mathrm{H}}_{2}\right), 3.89-$ $3.92(2 \mathrm{H}, \mathrm{t}, J 6.5 \mathrm{~Hz}, \mathrm{NCH}$ ) , 4.01-4.03 (4H, d, J $9.66 \mathrm{~Hz}, \mathrm{Cp}), 4.06(5 \mathrm{H}, \mathrm{s}, \mathrm{Cp}), 6.98-7.14(2 \mathrm{H}, \mathrm{m}, \mathrm{Im}), 7.49(1 \mathrm{H}, \mathrm{s}$, Im); ${ }^{13} \mathrm{C}$ NMR (100 MHz, CDCl 3$): \delta c 27.0,28.0,29.7\left(-\mathrm{CH}_{2}-\right)$, $45.9\left(\mathrm{NCH}_{2}\right), 66.1,66.9,67.3(\mathrm{Cp}), 87.9$ (C 118.23, 128.78, 136.64 (C-Im); Anal. Calc. for: $\mathrm{C}_{17} \mathrm{H}_{20} \mathrm{FeN}_{2}$ (308.21): C, 66.25; H, 6.54; Fe, 18.12; N, 9.09. Found: C, 65.98; H, 6.57; Fe, 18.27; N, 9.18\%.

1-(4-Ferrocenylbutyl)pyrazole (6f). From $0.4 \mathrm{~g}$ of 4-bromobutylferrocene, $0.21 \mathrm{~g}(57 \%)$ of light brown oil viscous oil (6f) was obtained. FT-IR ( $\left.\mathrm{KBr}, \mathrm{cm}^{-1}\right)$ : 3094, 29.35, 2857, 1610, 1440, 1390, 1000, 486; ${ }^{1} \mathrm{H}$ NMR (400 $\mathrm{MHz}): \delta_{\mathrm{H}} 1.44-1.52\left(2 \mathrm{H}, \mathrm{m},-\mathrm{CH}_{2}-\right), 1.86-1.93\left(2 \mathrm{H}, \mathrm{m},-\mathrm{CH}_{2}-\right), 2.32-2.36\left(2 \mathrm{H}, \mathrm{t}, J 7.6 \mathrm{~Hz}, \mathrm{CpCH}_{2}\right), 4.03-4.07(9 \mathrm{H}, \mathrm{m}$, $\mathrm{Cp})$, 4.11-4.15 (2H, t, NCH$), 6.23,7.36,7.56(3 \mathrm{H}, \mathrm{br}, \mathrm{py}) .{ }^{13} \mathrm{C} \mathrm{NMR}\left(100 \mathrm{MHz}_{2} \mathrm{CDCl}_{3}\right): \delta_{\mathrm{c}} 26.9,27.9,29.1,50.8$ ($\left.\mathrm{CH}_{2}{ }^{-}\right), 66.0,66.9,67.3(\mathrm{Cp}), 87.5$ (C 66.25; H, 6.54; Fe, 18.12; N, 9.09. Found: C, 66.79; H, 6.41; Fe, 17.89; N, 8.91\%.

1-(4-Ferrocenylbutyl)dipropylamine $(6 \mathrm{~g})$. From $0.4 \mathrm{~g}$ of 4-bromobutylferrocene, $0.28 \mathrm{~g}(69 \%)$ of light brown oil viscous oil $(6 \mathrm{~g})$ was obtained. FT-IR $\left(\mathrm{KBr}, \mathrm{cm}^{-1}\right): 2926,2854,1602,1410,1384,1003 ;{ }^{1} \mathrm{H} \mathrm{NMR}(400 \mathrm{MHz}): \delta_{\mathrm{H}}$ 0.86-0.89 (3H, t, J 7.3 Hz, CH3), 1.40-1.50 (8H, m, $\left.-\mathrm{CH}_{2}-\right)$, 2.31-2.43 (8H, m, CpCH, $\left.\mathrm{NCH}_{2}\right), 4.02-4.05(4 \mathrm{H}, \mathrm{m}, \mathrm{Cp})$, $4.09(5 \mathrm{H}, \mathrm{s}, \mathrm{Cp}) .{ }^{13} \mathrm{C} \mathrm{NMR}\left(100 \mathrm{MHz}, \mathrm{CDCl}_{3}\right): \delta_{\mathrm{C}} 10.9\left(\mathrm{CH}_{3}\right), 19.1,26.1,28.0,28.5\left(-\mathrm{CH}_{2^{-}}\right)$55.2, $53.0\left(\mathrm{NCH}_{2}\right), 65.9$, 66.9, 67.3 (Cp), 88.3 ( $C_{\text {ipso }} \mathrm{Cp}$ ). Anal. Calc. for: $\mathrm{C}_{20} \mathrm{H}_{31} \mathrm{FeN}$ (341.32): C, 70.38; H, 9.16; Fe, 16.36; N, 4.10. Found: C, 70.03; H, 9.29; Fe, 16.51; N, 4.17\%.

1-(4-Ferrocenylbutyl)dibutylamine (6h). From $0.4 \mathrm{~g}$ of 4-bromobutylferrocene, $0.34 \mathrm{~g}(78 \%)$ of light brown oil viscous oil (6h) was obtained. FT-IR $\left(\mathrm{KBr}, \mathrm{cm}^{-1}\right)$ : 3092, 2948, 2863, 1729, 1460, 1372, 1004, 490; ${ }^{1} \mathrm{H} N M R(400$ $\left.\mathrm{MHz}, \mathrm{CDCl}_{3}\right): \delta_{\mathrm{H}}$ 0.89-0.93 (6H, t, J 7.3 $\left.\mathrm{CH}_{3}\right), 1.25-1.34\left(4 \mathrm{H}, \mathrm{m},-\mathrm{CH}_{2}-\right), 1.38-.144\left(4 \mathrm{H}, \mathrm{m},-\mathrm{CH}_{2}-\right), 1.45-1.49(4 \mathrm{H}, \mathrm{m}$, $\left.-\mathrm{CH}_{2}-\right)$, 2.31-2.34 (2H, t, J 7.5 $\left.\mathrm{CpCH}_{2}\right), 2.38-2.41\left(6 \mathrm{H}, \mathrm{m}, \mathrm{NCH}_{2}\right), 4.02-4.03(2 \mathrm{H}, \mathrm{m}, \mathrm{Cp}), 4.04-4.05(2 \mathrm{H}, \mathrm{d}, \mathrm{J} 1.59$ $\mathrm{Hz}, \mathrm{Cp}), 4.09(5 \mathrm{H}, \mathrm{s}, \mathrm{Cp}) .{ }^{13} \mathrm{C} \mathrm{NMR}\left(100 \mathrm{MHz}, \mathrm{CDCl}_{3}\right): \delta_{\mathrm{c}} 13.1\left(\mathrm{CH}_{3}\right), 19.7,26.0,28.0,28.1,28.4\left(-\mathrm{CH}_{2^{-}}\right), 52.8$, $52.9\left(\mathrm{NCH}_{2}\right), 65.9,66.9,67.3(\mathrm{Cp}), 88.2$ (Cipso $\mathrm{Cp}$ ). Anal. Calc. for: $\mathrm{C}_{22} \mathrm{H}_{35} \mathrm{FeN}$ (369.37): C, 71.54; H, 9.55; Fe, 15.12; N, 3.79. Found: $C, 71.74 ; H, 9.47 ; F e, 15.02 ; N, 3.77 \%$. 
Synthesis of 4-(4-ferrocenylbutyl)-4-methyl morpholinium iodide (6i). 4-(4-ferrocenylbutyl)morpholine (6c) $(0.1 \mathrm{~g}, 0.31 \mathrm{mmol})$ and methyliodide $(0.13 \mathrm{~g}, 0.94 \mathrm{mmol})$ were dissolved in acetone $(20 \mathrm{ml})$ and the mixture was refluxed for 72 hours. After the completion of the reaction, the cooled mixture was diluted with ethyl acetate and washed with water. The organic phase was dried over $\mathrm{Na}_{2} \mathrm{SO}_{4}$, filtered, and the solvent was removed under atmospheric pressure. The crude product was purified by preparative thin layer chromatography on silica gel with $\mathrm{n}$-hexane/acetone (1:1) as eluent to give $0.09 \mathrm{~g}$ (91\%) of a light brown viscous oil (6i). FT-IR ( $\left.\mathrm{KBr}, \mathrm{cm}^{-1}\right)$ : 2923, 2853, 1602, 1412, 1384, 1035, 487. ${ }^{1} \mathrm{H}$ NMR (400 MHz, DMSO-d 6 ): $\delta_{H}$ 1.47-1.54 (2H, m, $\left.-\mathrm{CH}_{2^{-}}\right), 1.67-1.75\left(2 \mathrm{H}, \mathrm{m},-\mathrm{CH}_{2^{-}}\right), 2.33-2.37(2 \mathrm{H}, \mathrm{t}, \mathrm{J} 7.6 \mathrm{~Hz}, \mathrm{CpCH}), 3.11\left(3 \mathrm{H}, \mathrm{s}, \mathrm{CH}_{3}\right), 3.138-$ $3.41\left(4 \mathrm{H}, \mathrm{m}, \mathrm{OCH}_{2}\right), 3.45-3.48(2 \mathrm{H}, \mathrm{m}, \mathrm{NCH} 2), 3.91(4 \mathrm{H}, \mathrm{m}, \mathrm{NCH} 2) 4.06-4.12(9 \mathrm{H}, \mathrm{m}, \mathrm{Cp}) .{ }^{13} \mathrm{C} \mathrm{NMR}(100 \mathrm{MHz}$, DMSO-d $\left.)_{6}\right): \delta_{c} 20.7\left(\mathrm{CH}_{3}\right), 27.1,28.3,46.0\left(-\mathrm{CH}_{2}-\right), 58.9,59.8\left(\mathrm{NCH}_{2}\right), 63.5\left(\mathrm{OCH}_{2}\right), 66.9,67.7,68.3(\mathrm{Cp}), 88.1$

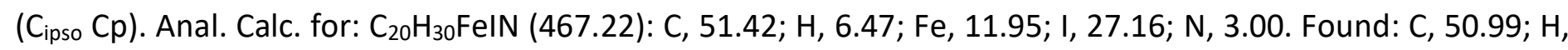
6.54; Fe, 12.12; I, 27.32; N, 3.03\%.

\section{Acknowledgements}

The authors thank Research Affairs of the University of Tabriz for financial support.

\section{References}

1. Pauson, P.L. J. Organomet. Chem. 2001, 637-639, 3.

https://doi.org/10.1016/S0022-328X(01)01126-3

2. Dave, R.V.S. and Nils, M.N. Chem. Rev. 2004, 104, 5931.

https://doi.org/10.1021/cr0101510

3. Sliwa, W. and Deska, M. Arkivoc 2011, (i), 496.

http://dx.doi.org/10.3998/ark.5550190.0012.110

4. Ceroni, P.; Bergamini, G.; Marchioni, F.; Balzani, V. Prog. Polym. Sci. 2005, 30, 453. https://doi.org/10.1016/j.progpolymsci.2005.01.003

5. Daniel, M. C.; Astruc, D. Chem. Rev. 2004, 104, 293. https://doi.org/10.1021/cr030698+

6. Jansen, J. F.; de Brabander-van den Berg, E. M.; Meijer, E.W. Science 1994, 266, 1226. https://doi.org/10.1126/science.266.5188.1226

7. Astruc, D. Pure Appl. Chem. 2003, 75, 461. https://doi.org/10.1351/pac200375040461

8. Wrona-Piotrowicz, A.; Plażuk, D.; Domagała, S.; Zakrzewski, J. Arkivoc 2012, (vi), 412. http://dx.doi.org/10.3998/ark.5550190.0013.636

9. Tian, W.; Datta, S.; Hong, S.; Reifenberger, R.; Henderson, J.; Kubiak, C. P. J. Chem. Phys. 1998, $109,2874$. https://doi.org/10.1063/1.476841

10. Richardson, D. E.; Taube, H. Coord. Chem. Rev. 1984, 60, 107. https://doi.org/10.1016/0010-8545(84)85063-8

11. Aguilar-Aguilar, A.; Peña-Cabrera, E.; Liebeskind, L. S. Arkivoc 2004, (i), 156. http://dx.doi.org/10.3998/ark.5550190.0005.11 
12. Drechsler, U.; Erdogan, B.; Rotello, V. M. Chem. Eur. J. 2004, 10, 5570. https://doi.org/10.1002/chem.200306076

13. Sporer, C.; Ratera, I.; Wurst, K.; Vidal-Gancedo, J.; Ruiz-Molina, D.; Rovira, C.; Veciana, J. Arkivoc 2005, (ix), 104.

http://dx.doi.org/10.3998/ark.5550190.0006.911

14. Astruc, D. New J. Chem. 2011, 35, 764.

https://doi.org/10.1039/c0nj00875c

15. Astruc, D. Angew. Chem. Int. Ed. Engl. 1988, 27, 643.

https://doi.org/10.1002/anie.198806431

16. Ornelas, C., Aranzaes, J. R., Cloutet, E., Alves, S., Astruc, D. Angew. Chem. Int. Ed. 2007, 119, 890. https://doi.org/10.1002/ange.200602858

17. Astruc, D.; Heuze, K.; Gatard, S.; Mry, D.; Nlate, S.; Plault, L. Adv. Synth. Catal. 2005, 347, 329. https://doi.org/10.1002/adsc. 200404247

18. Gasser, G.; Ott, I.; Nolte, N. M. J. Med. Chem. 2011, 54, 3.

https://doi.org/10.1021/jm100020w

19. Kumar, K.; Pradines, B.; Madamet, M.; Amalvict, R.; Benoit, N.; Kumar, V. Eur. J. Med. Chem. 2014, 87, 801. https://doi.org/10.1016/j.ejmech.2014.10.024

20. Ying, L.; lin, M. A. H.; Lei, H. A. N.; Wei-yong, L. I. U.; Zhao, B.; Zhang, S.; Miao, J. Acta Pharmacol. Sin. 2013, 34, 960.

21. Fouda, M. F. R.; Elzaher, M. M. A.; Abdelsamaia, R. A.; Labib, A. A. Applied Organomet. Chem. 2007, 21, 613.

https://doi.org/10.1002/aoc.1202

22. Schaumann, E. Science of Synthesis, Thieme: Stuttgart, 2008; Vol. 40, pp 7.

23. Margaretha, P. Science of Synthesis, Thieme: Stuttgart, 2002; Vol. 11, pp 109.

24. Senra, J. D.; Aguiar, L. C. S.; Simas, A. B. C. Curr. Org. Synth. 2011, 8, 53. https://doi.org/10.2174/157017911794407683

25. Surry, D. S.; Buchwald, S. L. Chem. Sci. 2011, 2, 27. https://doi.org/10.1039/COSC00331J

26. Rucker, R. P.; Whittaker, A. M.; Dang,H.; Lalic, G. J. Am. Chem. Soc. 2012, 134, 6571. https://doi.org/10.1021/ja3023829

27. Barker, T. J.; Jarvo, E. R. Angew. Chem. 2011, 123, 8475. https://doi.org/10.1002/ange.201103700

28. Loudon, M. Organic Chemistry, 5th Edn.; Roberts \& Company: Greenwood Village, 2009; Chap. 23.7A.

29. McMurry, J. Organic Chemistry, Cole, Belmont, 2012; Chap. 24.7.

30. Carey, J. S.; Laffan, D.; Thomson, C.; Williams, M. T. Org. Biomol. Chem. 2006, 4, 2337. https://doi.org/10.1039/b602413k

31. Azab, H. A.; Banci, L.; Borsari, M.; Luchinat, C.; Sola, M.; Viezzoli, M. S. Inorg. Chem. 1992, $31,4649$. https://doi.org/10.1021/ic00048a037

32. Anicet, N.; Anne, A.; Moiroux, J.; Saveant, J. M. J. Am. Chem. Soc. 1998, 120, 7115. https://doi.org/10.1021/ja9803097

33. Safa, K. D.; Abbasi, H.; Teimuri-Mofrad, R. J. Organomet. Chem. 2013, 740, 56. https://doi.org/10.1016/i.jorganchem.2013.04.027 
34. Safa, K. D.; Abbasi,H.; Teimuri-Mofrad R.; Charandabi, F. A. Aust. J. Chem. 2014, 6, 784. https://doi.org/10.1071/CH13632

35. Teimuri-Mofrad, R.; Abbasi, H.; Safa, K. D.; Tahmasebi, B. Arkivoc 2016, (iv), 371. http://dx.doi.org/10.3998/ark.5550190.p009.596

36. Teimuri-Mofrad, R.; Mirzaei, F.; Abbasi, H.; Safa, K. D. C. R. Chimie. 2017, 20, 197. https://doi.org/10.1016/i.crci.2016.06.011

37. Teimuri-Mofrad, R.; Safa, K. D.; Rahimpour, K. J. Organomet. Chem. 2014, 758, 36. https://doi.org/10.1016/j.jorganchem.2014.02.001 